\title{
A descriptive longitudinal analysis of the ownership structure of Spanish innovative companies
}

\author{
Juan Pablo Gonzales-Bustos \\ Universitat Rovira i Virgili \\ juanpablo.gonzales@urv.cat \\ Ana Beatriz Hernández-Lara \\ Universitat Rovira i Virgili \\ anabeatriz.hernandez@urv.cat
}

\begin{abstract}
This descriptive study makes a longitudinal analysis of the ownership structure of Spanish companies in innovative economic sectors. Our purpose is to contribute to the inconclusive research that analyses the impact of ownership structure on innovation by describing who the main blockholders of innovative companies in Spain are, determining the influence of domestic versus foreign capital, and exploring whether there are any significant differences when different time periods and different innovative sectors are compared. We collected data from 86 Spanish companies in innovative sectors between 2003 and 2014 (inclusive) which supplied a total of 898 observations. The results confirm that Spanish capital plays a bigger role than foreign capital in the ownership structure of Spanish innovative sectors, and that concentrated ownership by the board of directors, especially by affiliated directors, is also important. There are significant differences in the ownership structure of Spanish innovative sectors. However, its evolution over time is quite stable, with the exception of the proportion of executive ownership.
\end{abstract}

Keywords: Ownership structure; institutional ownership; domestic ownership, foreign ownership, typology of blockholders, innovative sectors, Spain 


\section{Introduction}

Previous research has shown the relevance of innovation for company survival and success (Kor, 2006). Innovation strategies allow companies to improve their competitive position (Wadhwa and Kotha, 2006) and their performance in the long-term (Zhou, 2006).

Companies' internal and external innovation strategies are influenced by numerous factors (Cassiman and Veugelers, 2006). From an internal perspective, corporate governance strongly affects corporate strategies, since it explains how the power of decision-making is distributed and shared within organisations. Previous research has highlighted the role played by ownership structure (Hoskisson et alii, 2002) as a crucial internal factor that influences decisionmaking and corporate strategies.

Corporate governance literature emphasises ownership structure as the most important research topic attempting to link corporate governance and innovation. According to Gonzales-Bustos and Hernández-Lara (2016), ownership structure is the most cited research topic in this literature, and features in more than $20.6 \%$ of the research papers that analyse this relationship; furthermore, its importance is growing over time. More specifically, ownership concentration and the existence of blockholders are traits of corporate governance that are particularly important in certain contexts and governance models, and analysing the influences of these blockholders on innovation has been considered a priority by previous research.

As far as the effects that ownership structure has on innovation, as we have mentioned above, the focus has been on the influence of ownership concentration (Kochhar and David, 1996; David et alii, 2001), and on the effects on innovation of different types of blockholders: for example, institutional (Choi et alii, 2011; 2012; David et alii, 2001; Kochhar and David, 1996), public (Choi et alii, 2011; Xiao and Zhao, 2012; Zeng and Lin, 2011), financial (Tribo et alii, 2007), or family ownership (Block, 2012; Chang et alii, 2006; Chen and Hsu, 2009). However, academic research has not reached a clear consensus on the effects that these characteristics of ownership structure finally exert on innovation. Some authors have found a positive association between ownership concentration and innovation efforts, measured as R\&D investments (Lee, 2012), whilst others have found a negative association (Brunninge et alii, 2007; Ortega-Argiles et alii, 2005; Zeng and Lin, 2011). And some studies have not been able to demonstrate any effects, positive or negative, of ownership concentration on innovation (Choi et alii, 2011; 2012). These incongruent results obtained by previous research have been explained by other kinds of effect, not only direct, but for example an 
inverted U-shape link, which would explain that when ownership concentration grows, its effect on innovation can be positive in a first stage, but afterwards can turn into negative when concentration becomes excessive (Liu, 2012). On the other hand, some other authors have explained the potential moderator effect exerted by blockholders. For example, Tsao and Chen (2012) considered that ownership concentration might moderate the relationship between internationalisation and innovation. Kim et alii (2008) studied how significant shareholders might moderate the association between the lack of financial resources and $\mathrm{R} \& \mathrm{D}$ investments, concluding that familiar ownership exerts a positive moderation effect, whilst institutional ownership and foreign capital have a negative moderation influence. Therefore, most studies try to justify the lack of consensus of the effects of ownership concentration considering that not all significant shareholders are the same. They do not constitute a homogeneous group with the same interests and objectives. On the contrary, they are different; they want and look for different goals and, therefore can exert different influences with their acts and decisions. But even so, when one specific type of blockholder is under analysis, not always its influences on innovation are clear.

The main objective of this study is to carry out a longitudinal descriptive research on the ownership structure of Spanish companies belonging to innovative sectors. Our purpose is to contribute to the inconclusive research that analyses the impact of ownership structure on innovation, describing who the main blockholders of innovative companies in Spain are, determining the influence of domestic versus foreign capital, and exploring whether some significant differences can be found or not when comparing over time and also among different innovative sectors.

Our results confirm that the most common major shareholders in the case of innovative companies in Spain are directors and shareholders of the same country. Among the different types of directors, affiliated directors are the most relevant in terms of the percentage of shares they hold in such companies. The lowest percentages of capital are those held by institutional owners, excluding financial institutions, and those held by executives directors. There are significant differences in the ownership structure of different Spanish innovative sectors, but the most and least relevant shareholders, in terms of their concentrated ownership, were almost the same in all the sectors compared. In addition, ownership structure in Spanish companies belonging to innovative economic sectors was stable over time. All in all, our results confirm that ownership structure in Spanish companies does not seem to foster an appropriate innovative environment for innovation. 
We aim to contribute to the literature not by trying to explain or predict innovation indicators through ownership structure, which is beyond our goal, but by analysing how is the ownership structure of innovative companies in Spain, who are their main shareholders, and if are there any differences when comparing companies of different innovative sectors and over time.

\section{Literature review on the effects of ownership structure on innovation}

There are many studies that suggest and try to demonstrate what the effects of ownership structure on innovation are, but few conclusive results have been finally reached, which makes this research line an interesting topic for academia.

Past researchers consider different theoretical perspectives to describe this relationship, being the most relevant ones, the agency and the stewardship theories. The agency theory highlights some key assumptions on the opportunistic behaviour of individuals, interested in satisfying their own objectives and goals. It could cause some agency costs in the case of organisations where there is separation between ownership and control (Eisenhardt, 1989). From the agency theory perspective, ownership structure is a key determinant of the innovation orientation of companies (Belloc, 2012), and more specifically, of R\&D investments (Lee and O'Neil, 2003). Also, this theory points out the incentives of blockholders to influence and control managers' decisions (Grossman and Hart, 1980).

The stewardship theory, on the other hand, assumes that managers are trustworthy individuals and believes that the different economic agents in companies are interested and will take profit at the end if the company's wealth improves (Davis et alii, 1997). Therefore, the interests of these agents, including managers and shareholders, would be aligned. This theoretical perspective, which has been not as important as the agency theory in previous research (Fox and Hamilton, 1994), also establishes that from its assumptions, shareholders wouldn't be interested in controlling and influencing managers' decisions.

From the opposite assumptions of these theoretical frameworks, it is not strange the scarce consensus found in previous research on the relationship between ownership structure and innovation. In the following sections, a literature review on the main arguments used by previous research to explain this association is exposed, considering the cases of the main types of blockholders. 


\subsection{Domestically vs foreign-owned companies}

Academic research underlines multiple differences between domestic and foreign ownership (Bellak, 2004), and its influence on innovation orientation is one of them. In this regard, previous research frequently agrees that domestically owned enterprises show a lower propensity to innovate (Britton, 2013; Love et alii, 2009). According to these studies, domestic ownership does not exert a significant influence on companies' innovation decisions (Dachs et alii, 2008). For example, Barros (2015) points out that both, domestically and foreign-owned companies, show the same innovative behaviour when the institutional environment is weak, not being evidence of significant differences among them. Other scholars have argued that it could be expected a negative influence of domestic ownership on innovation efforts (HyeogUg and Tomohiko, 2013). Dachs et alii (2008), for example, analysed how strong foreign-owned firms were embedded in the innovation systems of their host countries and found that foreign ownership is associated with similar levels of innovation input, but higher level of innovation output than domestically owned enterprises. This major propensity to innovate is influenced by the higher propensity to co-operate of affiliates of foreign multinationals with domestic partners than domestically owned companies.

Therefore, academic research has normally identified foreign ownership as one of the main drivers for international innovation and $R \& D$ activities (Choi et alii, 2011; Dachs et alii, 2008). According to these scholars, foreign ownership is directly associated with R\&D activities through the role of foreignowned enterprises' subsidiaries (Serapio and Dalton, 1999). As a matter of fact, numerous authors advocate for a positive influence of foreign ownership on innovation (Choi et alii, 2011; Love et alii, 2009; Resende et alii, 2014) and, more specifically, on R\&D expenses (Ferris and Park, 2005; Hwang et alii, 2013; Lee, 2012; HyeogUg and Tomohiko, 2013). These authors argue that foreign ownership offers better options to access to resources for innovation and R\&D development (Brugger and Stuckey, 1987; Choi et alii, 2011), allow technological resources to be transferred, a major technical collaboration, and higher exchange of managerial resources and funding (Love et alii, 2009).

\subsection{Institutional blockholders and financial owners}

Previous research has highlighted the relevance of institutional blockholders on companies' performance and results (McConnell and Servaes, 1990), and their orientation towards innovation (David et alii, 2001). In many countries, a high number of research and innovation projects have been possible thanks to the 
direct investments of different kind of institutions (Choi et alii, 2011). Various studies have empirically corroborated these positive effects of institutional blockholders on innovation (Choi et alii, 2011; 2012; David et alii, 2001; Kochhar and David, 1996), and on R\&D investments (Brossard et alii, 2013; Ferris and Park, 2005; Hill and Snell, 1988; Tribo et alii, 2007; Wahal and McConnell, 2000). According to these scholars, institutional investors are willing to promote innovative initiatives that contribute to a higher company's viability and competitiveness.

Nevertheless, not all the scholars agree with these positive influences, underlining that some institutional investors can be reluctant to risky and longterm investments (Graves, 1988). Therefore, the type of institutional owners may be decisive to determine their influence on innovation. Also, some studies consider other characteristics of institutional investors that can also affect their influence on innovation, for example, the term of the investments; long-term investments of institutional blockhoders positively affect innovation, whilst short-term investments exert a negative influence (Zahra, 1996). Finally, some research did not found any significant influence of institutional blockholders on innovation (Lee, 2012).

In order to clarify these conflicting propositions, researchers' tendency to view these investors as a monolithic group is changing (Zahra, 1996). One of the most relevant institutional owners that have attracted the interest of research are financial owners, like banks and other financial institutions. These institutions usually act as a key source of financial capital for great R\&D projects. In some countries, such as Germany, Spain, Japan and Sweden, banks are one of the most relevant companies' shareholders. They act as guarantors of innovation investments (Miozzo and Dewick, 2002), which support the positive association between banks ownership and R\&D investment, long-term commitments, and innovation (Lee, 2005; Miozzo and Dewick, 2002). However, literature is not always consistent regarding the effects of financial owners on R\&D and innovation. There are studies that did not find any significant effect of financial owners on innovation (Kochhar and David, 1996). Others found a significant negative association of this kind of blockholders on innovation (Tribo et alii, 2007), mainly explained by the business relationship that banks maintain with the firm in which they invest beyond simple ownership, in the form of loans and credits, which expose banks, normally conservative institutions, to the uncertainty of R\&D and innovation. 


\subsection{Great shareholders of the same economic sector vs great shareholders belonging to others economic sectors}

The economic activity developed by the company is one relevant factor of their innovative behaviour. There is a scarce body of research analysing the relationship between different types of relevant owners in terms of their economic activity and innovation. Among the studies interested in that, the most relevant arguments are based on the positive association of ownership belonging to companies of the same sector, with innovation activities and R\&D spending (Ito et alii, 2012), because normally the impact of companies' investments coming from the same sector is stronger and more committed in the long-term than investments coming from other industries (Harris and Moffat, 2013). These results have been supported most of the times in the case of multinational companies, where the subsidiaries in the host country gain a greater access to resources and a greater global connectivity beneficial for innovation, when the parent company and the subsidiaries belong to the same industry (Crescenzi et alii, 2015).

The studies that specifically analyse the effect of significant owners from other sectors on innovation do not arrive either to conclusive results. On the one hand, authors like Miozzo and Dewick (2002) argued a positive relationship, based on the possibility of national companies to invest in specific innovation activities in which they are interested as a consequence of investments that come from companies in other sectors. Van der Elsta (2004), on the other hand, pointed out that different industries do not share the same characteristics, interests and needs, which explain that investments from other economic sector do not favour innovation.

\subsection{Ownership held by the board: executive, affiliated and independent ownership}

Previous research has highlighted the influence that directors' ownership can exert on firms' innovative behaviour (Westphal and Zajac, 1995). However, again conclusive results were not found in this research. Scholars like Hoskisson et alii (1993) or Zahra (1996) established that board ownership drove to a greater look for their self-interest, and this could motivate directors to increase their efforts to get external resources to foster innovation. However, lately other authors, like Kim and Kim (2015) have not found any significant relationship between stocks held by the board and innovation.

This lack of agreement can respond to the different types of directors involved in the board. Firstly, executive ownership refers to stocks held by directors closely 
related to managerial positions. In companies where shareholders also participate in management, the board can be more centred in its strategic function and less in its monitoring and control roles (Brunninge et alii, 2007; Chen and Hsu, 2009). Under these arguments, previous research has stated that executive ownership exerts a positive influence on risky strategies favouring innovation (Zajac and Westphal, 1994). Zahra (1996) also found evidence on the positive association between executive ownership and innovation. Some possible explanations arise from the fact that executive owners show a major propensity to invest in long-term projects instead of maximizing benefits in the short-term (Sundaramurthy and Lewis, 2003). Nevertheless, executive owners could also exert a negative influence on risky strategies (Jensen and Meckling, 1976) due to the deceleration that they cause on innovation spending (Choi et alii, 2011; Latham and Braun, 2009; Zeng and Lin, 2011). Other studies analysed the moderating effects provoked by executive ownership. For example, Kim and Kim (2015) found evidences on the positive moderating effect of executive ownership on the relationship between board capital diversity and innovation results, which maintain an inverted U-shaped relationship. Hernández-Lara et alii (2014), on the other hand, did not find any significant effect of executive owners on innovation.

Secondly, previous research has pointed out that affiliated ownership could reduce agency costs (Chang, 2003; Chang and Hong, 2000), favouring risky strategies. According to these studies, stocks held by affiliated directors make stronger the links with other companies and the access to a wider network. Overall, this can improve the advice received by managers and exert a positive influence on innovation. Other authors, like Hernández-Lara et alii (2010; 2014), argued that affiliated ownership significantly and positively moderates the relationship between the proportion of affiliated directors and innovation. According to them, affiliated ownership can empower affiliated directors and makes them more actively involved in their monitoring and control functions, improving the companies' innovation strategies when their representation in the board growths.

Finally, independent directors who hold significant percentages of shares are more involved in discussions within the companies about their innovative orientation (Zahra, 1996). According to Hoskisson et alii (1993), independent directors with significant stocks show a higher propensity to risky projects, like R\&D spending and innovation. Other scholars stated a moderating effect exerted by this kind of owners, because they can mitigate the negative association between a high proportion of executive directors and innovation (Zahra, 1996). 
In this literature review on the effects of ownership structure on innovation, it has become clear the inconclusive results of this research. We aim to contribute to the literature not by trying to explain or predict innovation indicators through ownership structure, but by analysing how is the ownership structure of innovative companies in Spain, who are their main shareholders, and if are there any differences when comparing companies of different innovative sectors and over time.

\section{Methodology}

\subsection{Data collection}

The data were collected from Spanish companies listed on the Spanish stock exchange between 2003 and 2014. We initiated the data collection in 2003 coinciding with the publication of the Aldama report (2003), and the relevance given to corporate governance issues in the Spanish context (Gonzales-Bustos and Hernández-Lara, 2014).

Using information from the Spanish Institute of Statistics, we selected firms from sectors that showed significantly high innovation indicators, such as the percentage of innovative firms (above 50\%), innovation intensity (above 1.5\%), and the percentage of income generated by new or improved products (above 10\%). Considering the divisions or sections of the National Classification of Economic Activity (NACE 2009) in Spain (INE, 2009), five sectors were included: energy and water supply, extractives, construction, industry and services, all of them considered as innovative economic sectors. The final sample comprised 86 Spanish-listed companies from the chosen sectors, with data covering twelve years, so we could construct an imbalanced data panel of 898 observations ( 88 observations belong to the construction sector, 41 to the energy and water supply sector, 28 to extractives companies, 388 to industry firms and 353 to companies in the service sector).

We conduct this study using secondary sources of information. The database of the CNMV (Spanish Security Exchange Commission) was the main resource used to gather information on ownership structure.

\subsection{Measurement of variables}

All the variables of this study are related to ownership structure, considering different types of blockholders or significant shareholders. CNMV in Spain determines at any time the percentage of capital that a shareholder must have to be considered as significant, being now this percentage at 3\%; and even more, 
Spanish companies listed on the Spanish stock exchange must inform in their corporate governance reports about the identity of their significant shareholders and the percentage of capital held by them.

Under this premise, we measured domestic capital as the sum of the significant percentages of capital held by domestic blockholders (HyeogUg and Tomohiko, 2013), it means Spanish great shareholders, which could be institutional or financial investors, companies of the same or other sectors and individual investors.

Foreign capital is determined as the sum of the significant percentages of capital held by foreign investors (Love et alii, 2009), being these investors again of different kinds, such as institutional or financial investors, companies of the same or other sectors and individual investors.

We considered institutional capital as the sum of significant participations held by institutions, like pension funds, insurance companies or investment societies (Ferris and Park, 2005; Zahra, 1996), with the exception of financial institutions and banks, both Spanish and foreign ones.

Financial capital is measured through the sum of significant participations held by financial institutions and banks (Tribo et alii, 2007), both from Spain and from other countries.

Capital of companies of the same sector is measured as the aggregation of significant percentages of ownership held by companies belonging to the same sector or in the same economic activity than the firm under consideration (Ito et alii, 2012).

Capital of companies of other sectors is measured as the aggregation of significant percentages of ownership held by companies belonging to different sectors or economic activities, different from the economic activity of the company under consideration, and excluding financial and institutional investors (Ito et alii, 2012).

Board ownership is determined through the significant ownership held by the board of directors (Kim and Kim, 2015).

Executive ownership is measured as the significant ownership held by executive directors (Hoskisson et alii, 2002).

Affiliated ownership is calculated as the significant ownership held by affiliated directors (Hernández-Lara et alii, 2014).

Independent ownership is measured as the significant ownership held by independent and external directors (Zahra, 1996).

The amount of ownership held by every type of shareholder was calculated through the aggregation of the percentages of shares of the significant shareholders of this kind, being considered a shareholder as significant when having $3 \%$ or more of the company's capital. 


\section{Results}

The statistical analyses of this work were carried out using $R$, version 3.2.0. ( $R$ Core Team, 2015).

Table 1 shows descriptive statistics of ownership structure in terms of the most important types of blockholders, described as our variables.

Table 1: Descriptive statistics of ownership structure (percentages of significant capital held by blockholders)

\begin{tabular}{|l|c|c|c|c|}
\hline Types of blockholders & Min & Max & Mean & Sd \\
\hline Domestic & 0.000 & 100.000 & 30.63 & 27.753 \\
\hline Foreign & 0.000 & 99.74 & 13.77 & 21.933 \\
\hline Institutional & 0.000 & 91.31 & 4.379 & 12.196 \\
\hline Financial & 0.000 & 95.600 & 4.725 & 10.283 \\
\hline Companies of the same sector & 0.000 & 99.74 & 8.458 & 19.940 \\
\hline Companies of other sectors & 0.000 & 99.480 & 17.599 & 24.852 \\
\hline Board & 0.000 & 100.000 & 54.07 & 26.934 \\
\hline Executive directors & 0.000 & 72.560 & 5.324 & 13.360 \\
\hline Affiliated directors & 0.000 & 99.48 & 37.07 & 28.147 \\
\hline Independent directors & 0.000 & 99.740 & 11.672 & 19.610 \\
\hline
\end{tabular}

$\mathrm{N}=902$

As Table 1 shows, the mean values of the percentages of significant ownership held by the most relevant shareholders indicate that domestic capital $(30.63 \%)$ and ownership held by the board $(54.07 \%)$ are the highest, which means that the most common major shareholders in the case of innovative companies in Spain are directors and shareholders of the same country. Among the different types of directors, affiliated directors $(37.07 \%)$ are the most relevant in terms of the percentage of shares they hold in such companies. The lowest percentages of capital are those held by institutional owners (4.379\%), excluding financial institutions, and executives directors (5.324\%).

To analyse the differences in the ownership structure considering different innovative sectors, we conducted one-way ANOVA analyses and determined the mean values of significant ownership held by the different blockholders in each sector. The results of these analyses are included in Table 2 . 
Table 2: Mean values of ownership structure by sectors

\begin{tabular}{|l|c|c|c|c|c|c|}
\hline \multirow{2}{*}{\begin{tabular}{c}
\multirow{2}{*}{$\begin{array}{c}\text { Types of } \\
\text { blockholders }\end{array}$} \\
\cline { 2 - 7 }
\end{tabular}} & $\begin{array}{c}\text { Energy } \\
\text { and water } \\
\text { suppy }\end{array}$ & Extractives & Construction & Industry & Services & \multirow{2}{*}{ F } \\
\hline Domestic & 26.732 & 34.498 & 45.887 & 26.328 & 31.131 & $15.04^{* * *}$ \\
\hline Foreign & 35.789 & 2.047 & 10.660 & 15.116 & 11.500 & $162^{* * *}$ \\
\hline Institutional & 4.880 & 3.490 & 0.759 & 5.233 & 4.202 & $5.093^{* *}$ \\
\hline Financial & 8.290 & 3.360 & 6.849 & 4.023 & 4.449 & $2.297+$ \\
\hline $\begin{array}{l}\text { Companies of the } \\
\text { same sector }\end{array}$ & 33.558 & 16.544 & 18.904 & 3.950 & 7.166 & $88.44^{* * *}$ \\
\hline $\begin{array}{l}\text { Companies of other } \\
\text { sectors }\end{array}$ & 13.707 & 9.057 & 26.168 & 14.857 & 19.532 & $21.4^{* * *}$ \\
\hline Board & 63.912 & 44.611 & 60.278 & 53.469 & 52.189 & $25.4^{* * *}$ \\
\hline Executive directors & 0.767 & 2.658 & 3.977 & 7.263 & 4.035 & $18.1^{* * *}$ \\
\hline Affiliated directors & 21.701 & 12.105 & 48.999 & 32.706 & 42.248 & $57.5^{* * *}$ \\
\hline $\begin{array}{l}\text { Independent } \\
\text { directors }\end{array}$ & 41.443 & 29.848 & 7.301 & 13.499 & 5.906 & $88.42^{* * *}$ \\
\hline
\end{tabular}

${ }^{* * *} \mathrm{p}<0.001 ;{ }^{* *} \mathrm{p}<0.01 ;{ }^{*} \mathrm{p}<0.05 ;+\mathrm{p}<0.1$

As Table 2 shows, again the most and least important blockhoders are the same when comparing the different Spanish innovative sectors. Domestic blockholders and the board are the most relevant shareholders. Both types of blockholders show the highest percentages of capital most of the times, considering the different economic innovative sectors. We must highlight only one exception, for companies in the "energy and water supply" industry. In this case, foreign blockholders (35.789\%) are more important than domestic ones $(26.732 \%)$, contrary to the others sectors. In addition, although the board ownership is the highest in this sector, it is due to the high percentage of ownership held by independent directors, not affiliate directors who are normally the type who owns normally more shares. The board ownership is the highest in all the sectors, especially due to the capital held by affiliate directors, with the exception of "energy and water supply" as we have established before, and "extractive industries". Executive directors are the least relevant in terms of their ownership. Again, in these two sectors, the ownership of companies belonging to the same sector is more important than the ownership of companies from other activities, contrary to the other three sectors where it is more relevant the ownership held by companies developing different economic activities than the firm under consideration. In general, institutional, financial and executive blockholders are the ones less relevant in terms of their concentrated ownership. Another interesting result that we can extract from Table 2, is that there are 
significant differences among economic innovative sectors in all the different types of blockholders taken into account. It means that the average values of concentrated ownership held by each type of blockholders in each sector cannot be considered the same.

This study is also interested in determining the evolution of the ownership structure in Spanish innovative companies over time. To this end, we develop graphical analyses of how the mean values of the variables considered have been evolving over time, and also by sectors.

Figure 1: Evolution of domestic capital

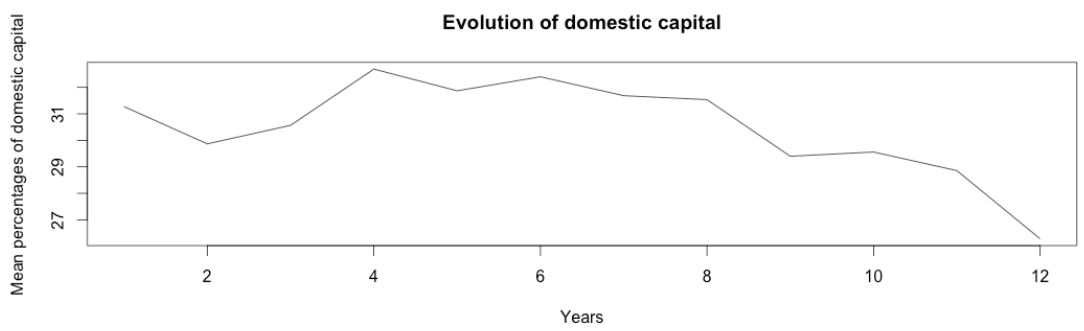

Figure 2. Evolution of the percentage of domestic capital by sector

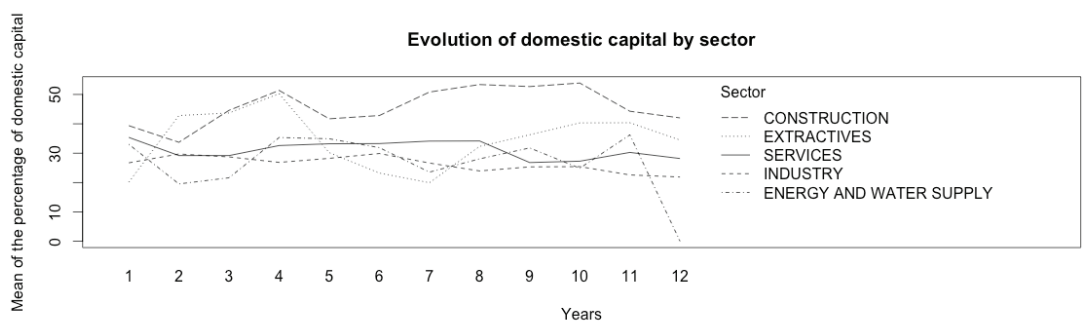

Figures 1 and 2 refer to domestic capital. Figure 1 shows a negative tendency in the concentrated domestic ownership practically since 2006, with the lowest level reached in 2014. So, it means that despite the relevance of this type of blockholder, its relevance is diminishing over time. By sectors, Figure 2 shows that "energy and water supply" is the sector with highest domestic ownership, whilst "industry" has the smallest levels. We can also observe some oscillations in concentrated domestic capital of the different sectors, but these changes over time are not significant. The only significant differences can be found in the mean values of this kind of concentrated ownership when considering different innovative sectors. 
Figure 3: Evolution of foreign capital

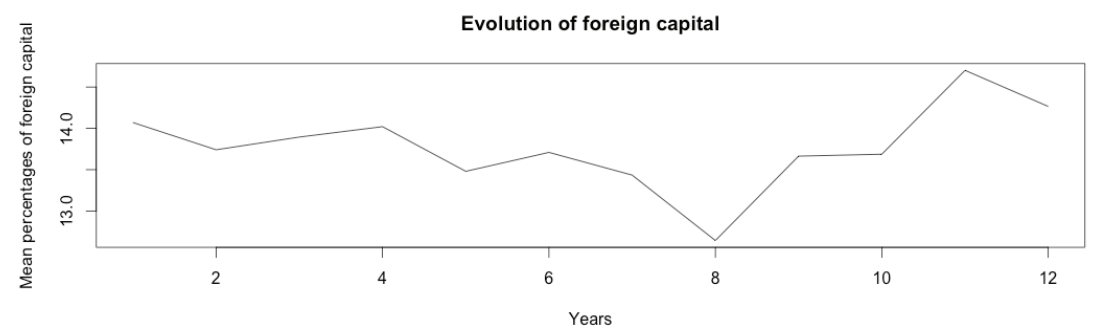

Figure 4: Evolution of the percentage of foreign capital by sector

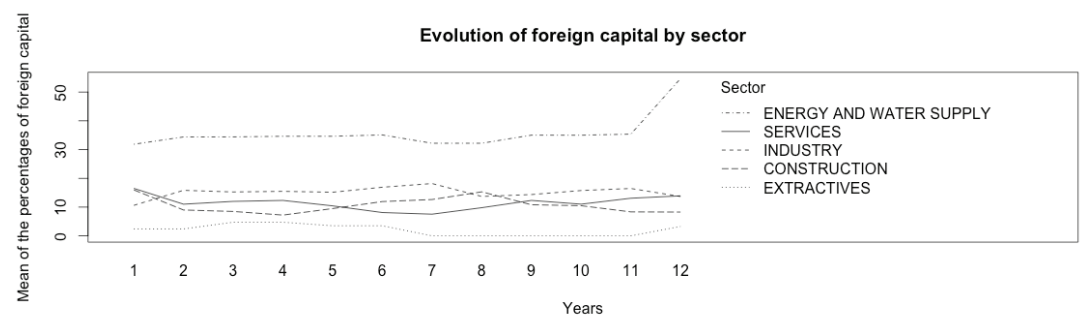

Figures 3 and 4 are related to foreign capital. As we can see, foreign capital is low in Spanish innovative sectors but its evolution has been positive since 2010 until 2013, with a little recession in 2014. The evolution of this variable is quite stable in all sectors, with the exception of "energy and water supply", which reduces to $0 \%$ their domestic capital in 2014 , and show the highest level of foreign capital this year (54.695\%). As a matter of fact, all the sectors are quite close in terms of their foreign capital except "energy and water supply", which shows statistically significant higher levels. On the other hand, the sector with lower foreign capital is the "extractive industry".

Figure 5: Evolution of institutional capital

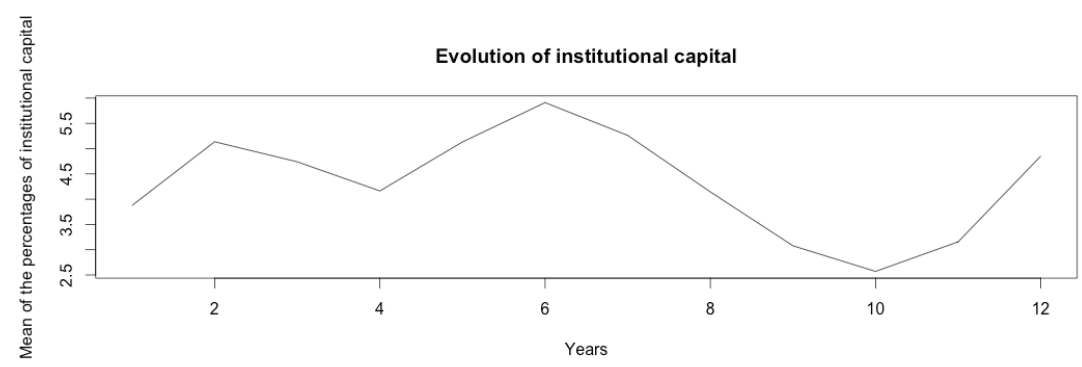


Figure 6: Evolution of the percentage of institutional capital by sector

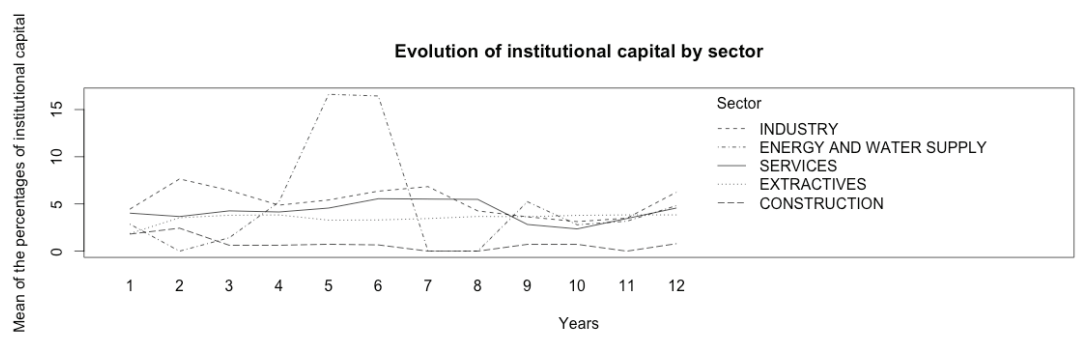

Figures 5 and 6 refer to institutional capital. Figure 5 indicates that the percentage of institutional ownership has been very low in the period considered, and it has been increasing just a little bit since 2012. As Figure 6 shows, the different sectors do not exhibit big changes over time, except "energy and water supply", which has relevant levels of this type of ownership in the middle of the period under consideration. The sector with more foreign capital is "industry" and the one with lower levels of this kind of ownership is "construction", but in none of the economic activities considered is this kind of ownership predominant.

Figure 7: Evolution of financial capital

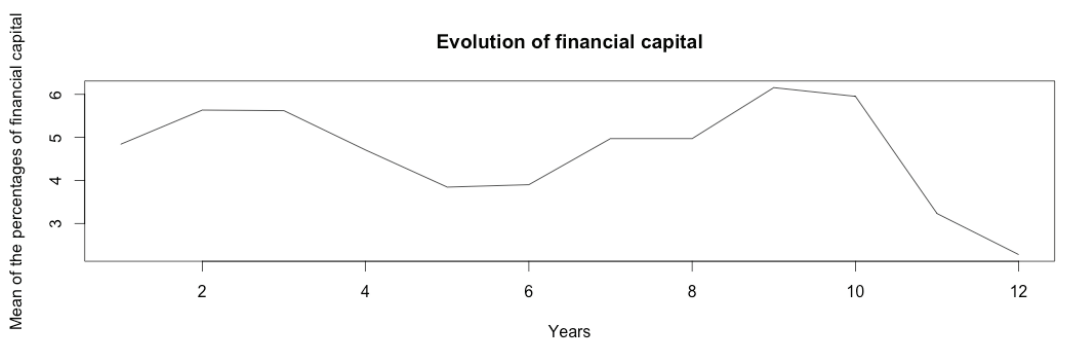

Figure 8: Evolution of the percentage of financial capital by sector

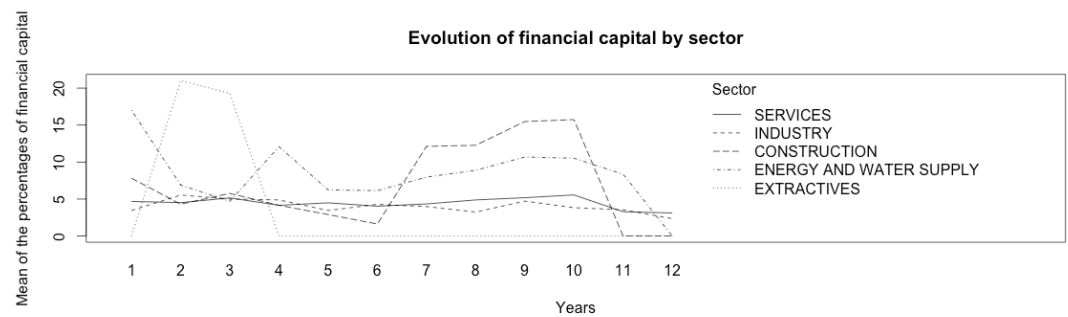


Figures 7 and 8 are related to financial capital. The percentage of this kind of concentrated ownership has evolved negatively since 2012. In addition, the evolution of this ownership has been quite irregular in all sectors over time, although at the end of the period all the sectors are quite close."Energy and water supply" has been the sector with a major proportion of financial ownership and "extractives industries" are the sector with the fewest.

Figure 9: Evolution of capital held by companies in the same sector

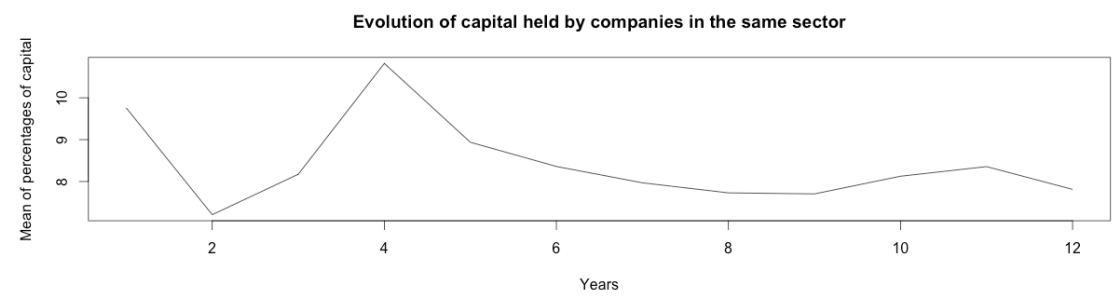

Figure 10: Evolution of the percentage of capital held by companies with the same activity by sector

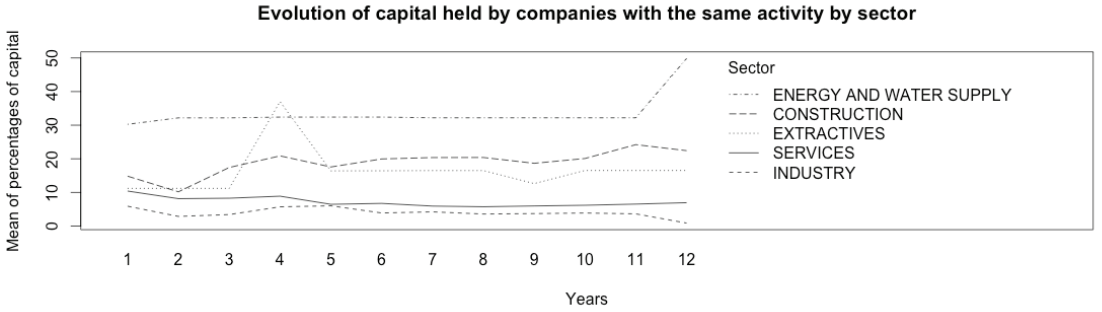

Figures 9 and 10 show the percentages of capital held by companies belonging to the same sector than the firm under consideration. Their evolution has been quite irregular with negative tendency since 2006. By sectors, relevant differences can be observed, although the evolution is quite stable in each one. The "extractive industry" has the highest level of this kind of property, whilst the "industry" has the lowest. 
Figure 11: Evolution of capital held by companies in other sectors

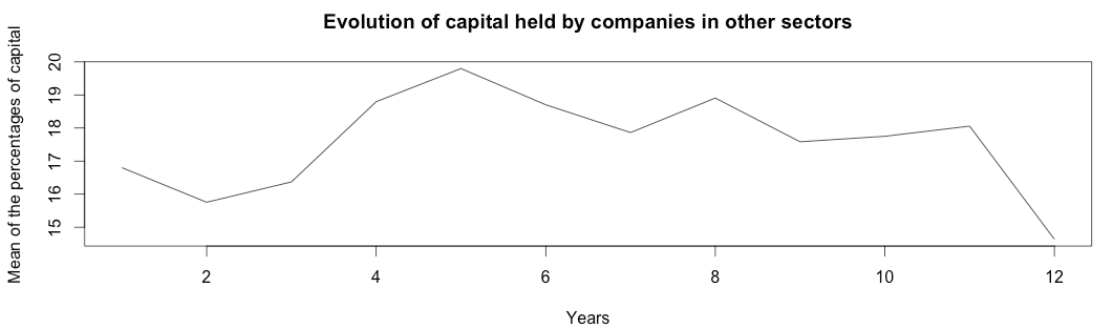

Figure 12: Evolution of the percentage of capital held by companies with different activities by sector

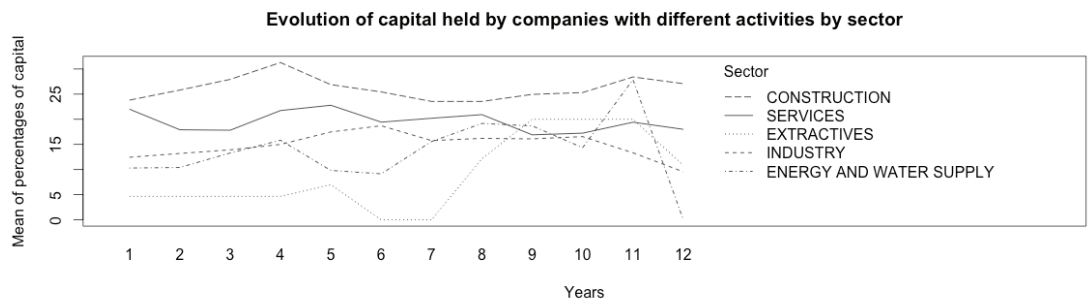

Figures 11 and 12 are related to concentrated ownership held by companies of other sectors. We can observe again an evolution quite unstable, with successive ups and downs, but with a general negative tendency, especially since 2007. By sectors, we can observe that some economic activities are more stable than others regarding the proportion of capital held by companies belonging to other sectors. The sectors with bigger changes in the evolution of this variable are "energy and water supply" and "extractive industries". The sector where this kind of blockhoders is more important is "construction", and where is less important, it depends on the moment, but in general terms are "industry" and "extractives".

\section{Figure 13: Evolution of board capital}

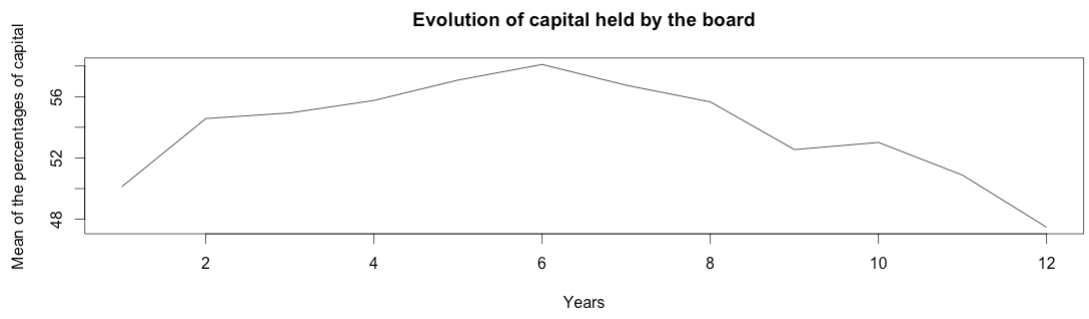


Figure 14: Evolution board capital by sectors

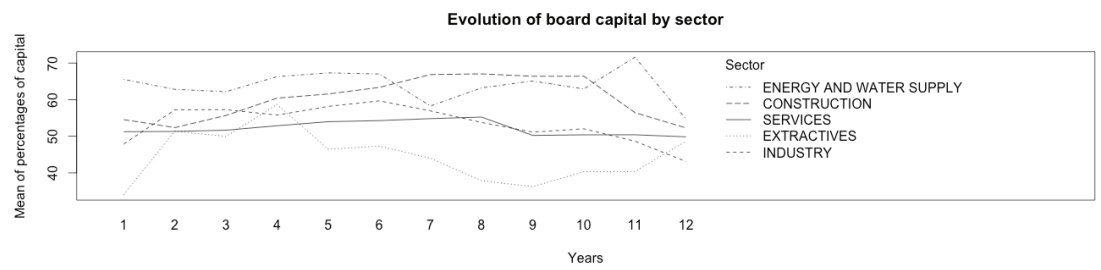

Figures 13 and 14 show concentrated ownership held by the board of directors in Spanish companies belonging to innovative sectors. The general evolution highlights a positive growth in this type of shareholder until 2008, and a decrease after that. Considering the different sectors, although the values and tendency are different in each economic activity, at the end, it can be observed that the mean values in the proportion of the board ownership is quite close considering the different sectors. "Energy and water supply" and "construction" have the highest proportion of this kind of ownership, and "extractives" and "industry" the lowest.

Figure 15: Evolution of executive capital

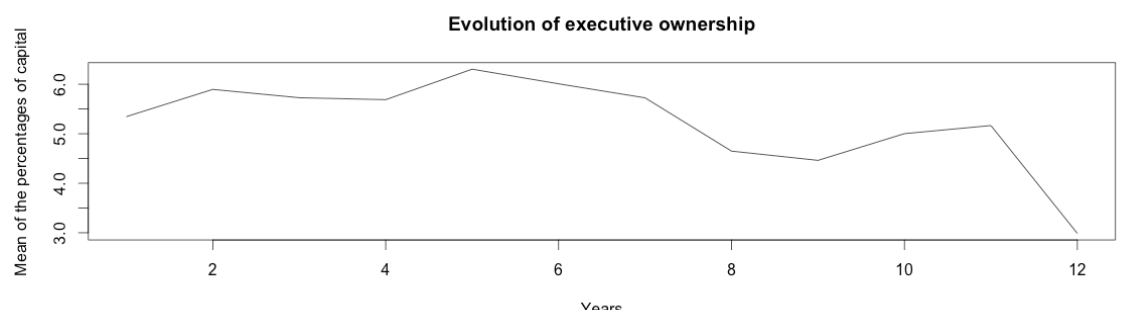

Figure 16: Evolution executive capital by sectors

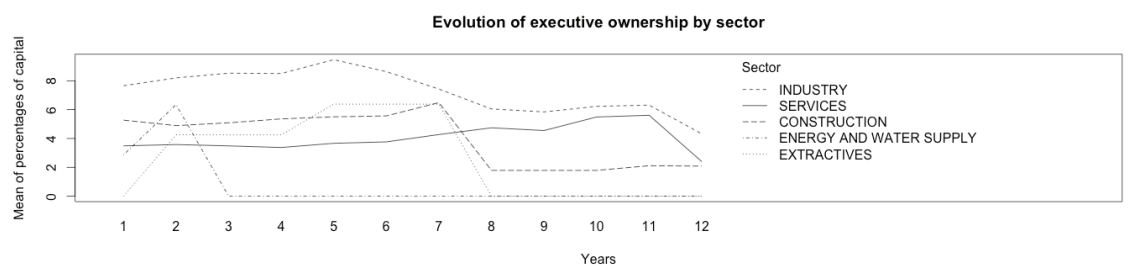

Figure 17: Evolution of affiliated capital

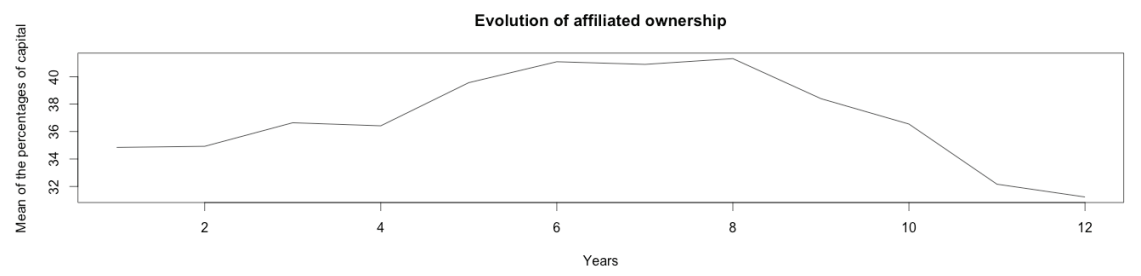


Figure 18: Evolution affiliated capital by sectors

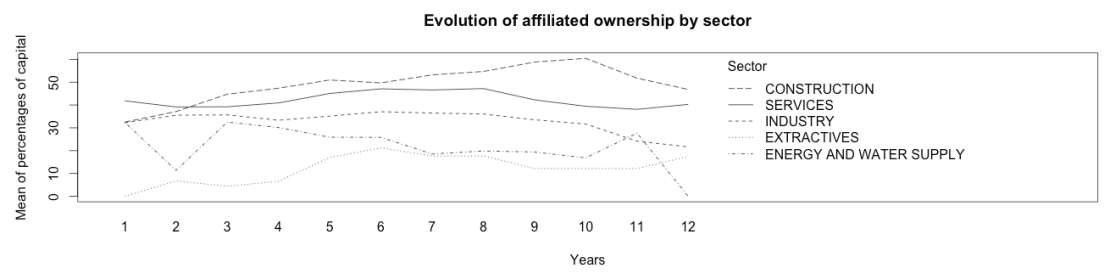

Figure 19: Evolution of independent capital

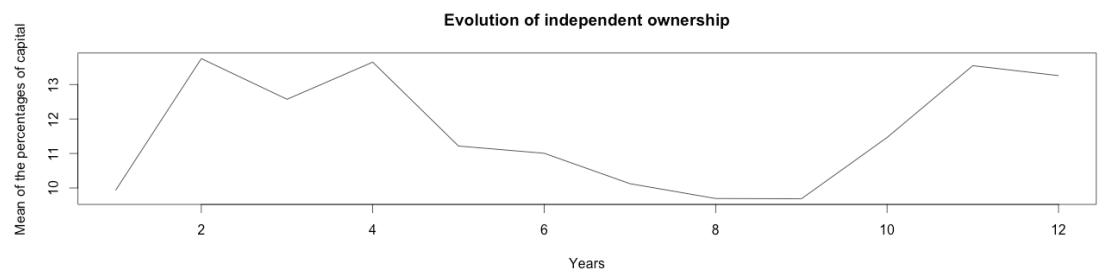

Figure 20: Evolution independent capital by sectors

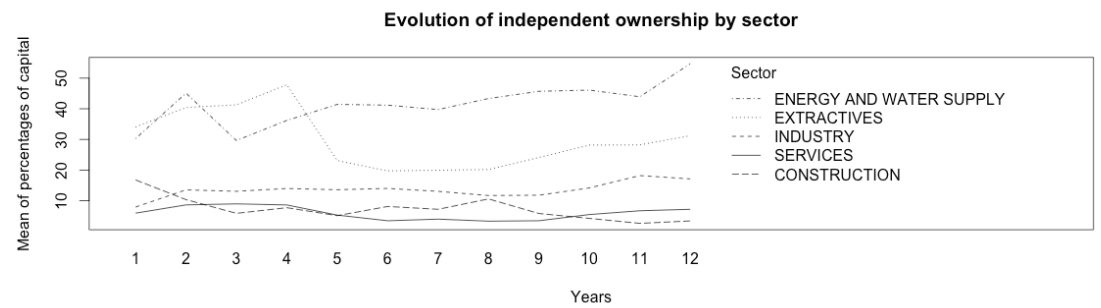

Finally, the last Figures are related to concentrated ownership held by different kind of directors. Figures 15 and 16 refer to executive ownership; Figures 17 and 18 are related to affiliated ownership; and Figures 19 and 20 refer to independent ownership. The general tendency regarding the existence of executive and affiliated blockhoders is quite similar, with an increase at the beginning of the period under consideration, and a decrease afterwards. It is contrary to what happens with independent ownership, which shows an important growth since 2011. Comparing these three types of blockhoders, the most relevant are affiliated directors, followed by independent directors, and finally the less important are executive ones. By sectors, executive ownership is especially relevant in "industry" and the lowest importance of this kind of capital is shown by "extractives" and "energy and water supply". In terms of affiliated ownership, the sector where this kind of capital is highest is "construction" and "services" and where it is lower is in the "extractive industries". Finally, regarding independent ownership, in "energy 
and water supply" is where this kind of capital is more important, and in "services" and "construction" is where the relevance of these blockhoders is lower.

Table 3 indicates the mean values by sector and year of each of the variables of this study, and also includes statistics tests to analyse the effects of time and the economic activity on the mean values of the variables considered. As we can see, the mean values of all the variables are significantly different amongst sectors. On the contrary, the effect of time is not significant. The results confirm that time only yields significant differences in the proportion of executive ownership. It means that the negative evolution of executive ownership is significant over time. On the other hand, for the rest of the types of significant shareholders, we have not detected significant differences over time. 


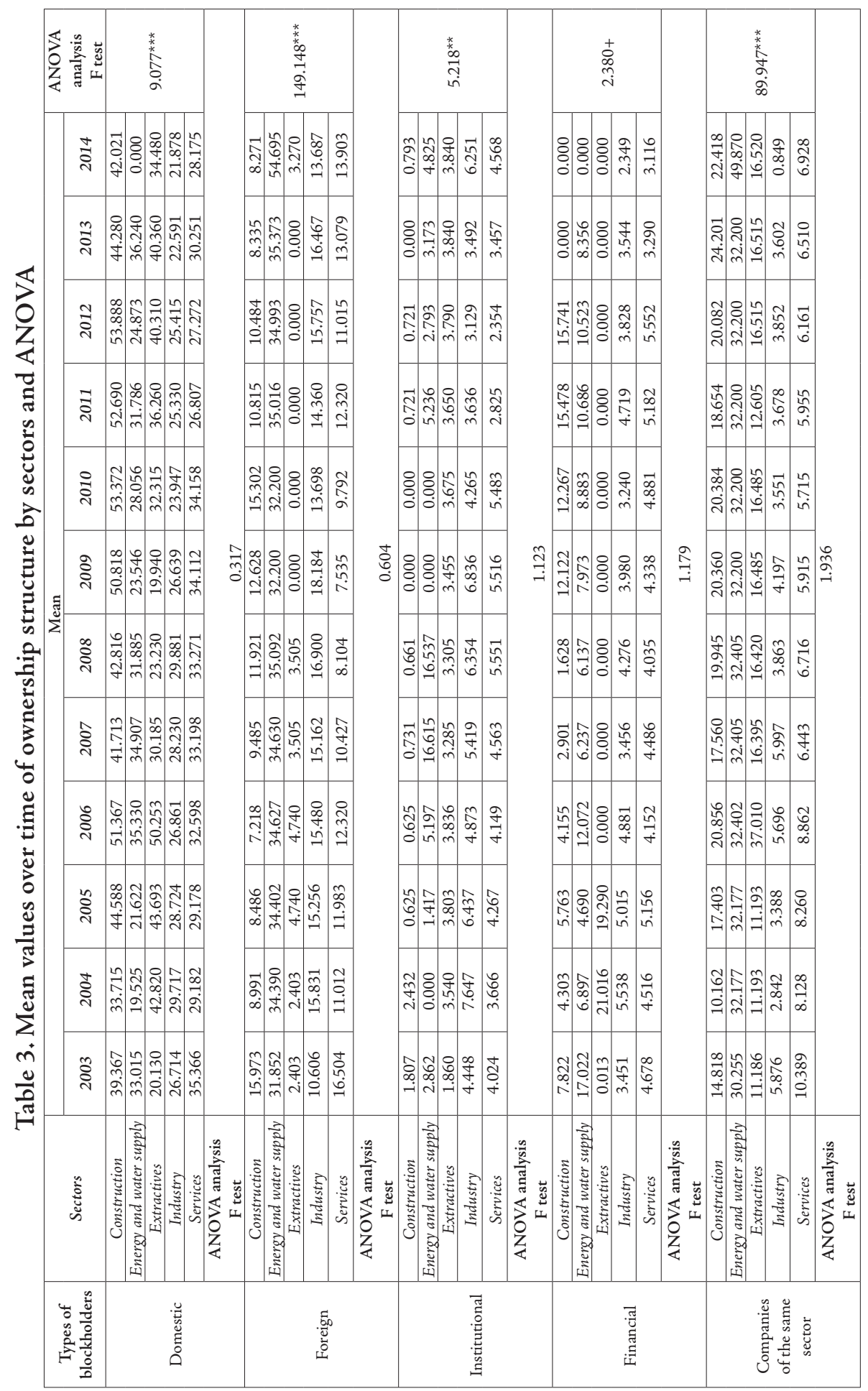




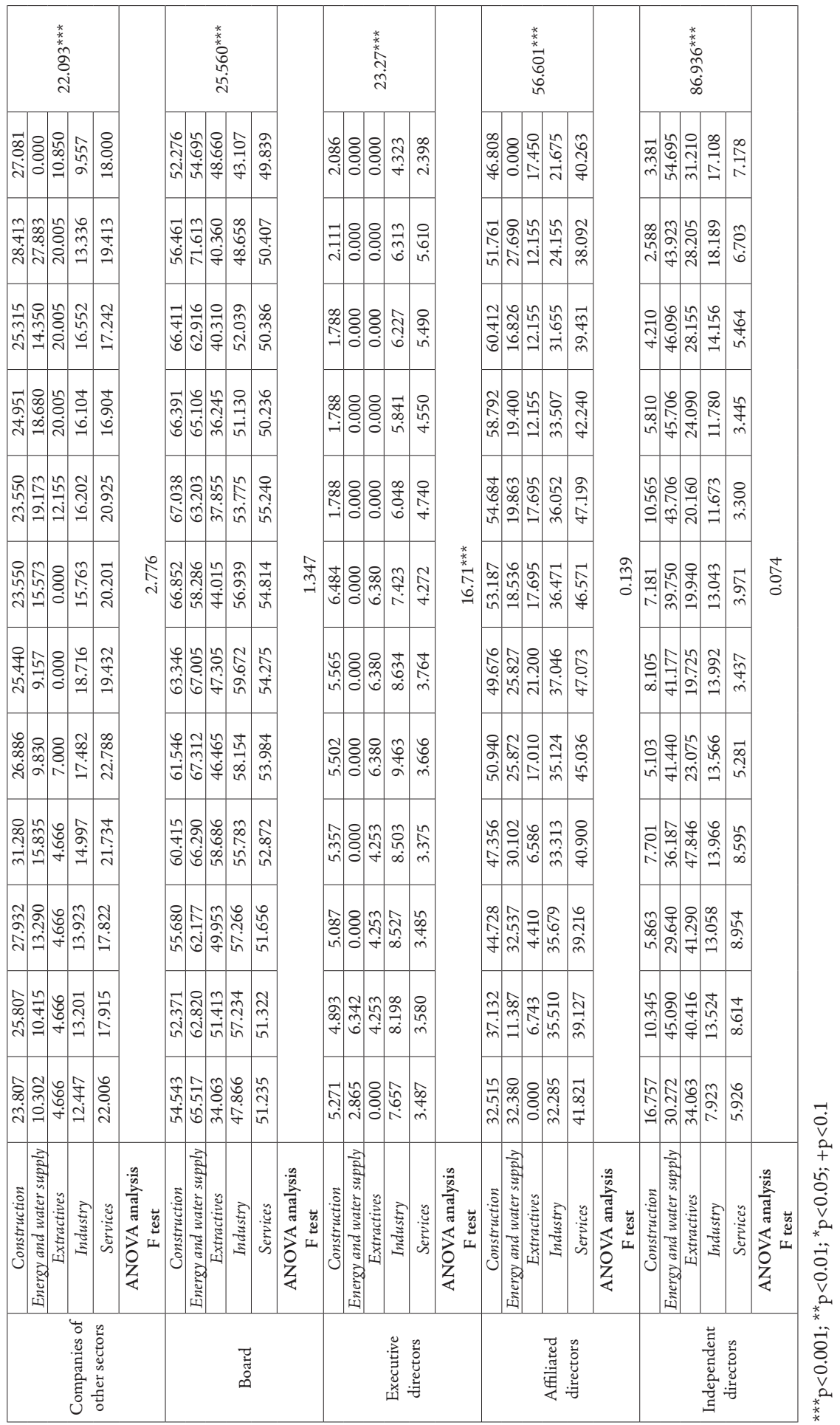




\section{Discussion and conclusions}

The main goal of this study was to develop a longitudinal analysis of ownership structure of Spanish companies that belong to innovative economic sectors. Our purpose was just to describe who are the main blockholders of innovative companies in Spain and explore whether or not some significant differences can be found when comparing over time and also among different innovative sectors. Therefore, this study is far from traditional research on this topic that is normally based on analysing the effects that ownership concentration and significant stocks held by different types of stockholders exert on innovation. Previous results of this research have not been conclusive, which lead us to make a first step in this matter, and develop a descriptive analysis trying to state if it is possible to extract some common traits when ownership structure of Spanish innovative companies are considered, comparing its evolution over time and also among different innovative economic sectors. These conclusions could be especially relevant in a context like Spain where the government has been trying to boost R\&D and innovation activities in the last years but where the innovation intensity is still below the average of European Union and also OECD countries (HernándezLara et alii, 2014).

The main findings of this study show that the most common major shareholders in the case of innovative companies in Spain are directors and shareholders of the same country. Among the different types of directors, affiliated directors are the most relevant in terms of the percentage of shares they hold in such companies. The lowest percentages of capital are those held by institutional owners, excluding financial institutions, and executives directors. When different innovative economic sectors are compared, again the most and least important blockholders are the same; domestic blockholders and the board are the most relevant shareholders. We must highlight only one exception, for companies in the "energy and water supply" industry. In this case, foreign blockholders are more important than domestic ones, and independent directors are the most relevant shareholders in the board, not affiliate directors who are normally the type who owns more shares. In "energy and water supply" and "extractive industry", the ownership of companies belonging to the same sector is more important than the ownership of companies from other activities, contrary to the other three sectors, "construction", "industry" and "services". In general, institutional, financial and executive blockholders are the ones less relevant in terms of their concentrated ownership. These are the general conclusions about who are the main blockholders when different innovative Spanish economic sectors are compared. Also, significant differences were found in the mean values of 
concentrated ownership held by different blockholders among sectors. It means that ownership structure is not really the same among these sectors; each sector has their own particularities regarding the percentages of capital held by different blockhoders. Nevertheless, although the percentages of capital were not exactly the same, it does not invalidate that the most and least relevant shareholders, in terms of their concentrated ownership, were the same in the different innovative economic sectors compared.

The singularities observed mainly in the case of the "energy and water supply" sector are motivated by the low number of companies in this sector and the specific ownership structure of some of its companies, characterised by a high presence of foreign and independent blockholders, which at the end exert a clear influence on the average values of the whole sector. We could have decided to remove these companies of our sample, but we considered that this decision would damage to obtain a real picture of the ownership structure of the Spanish stock exchange listed companies in the "energy and water supply" sector.

Other important finding of this research was that the effect of time was not significant. Specifically, time only yielded significant differences in the proportion of executive ownership. For the rest of the types of significant shareholders, we have not detected significant differences over time, which means that ownership structure in Spanish companies belonging to innovative economic sectors was stable over time.

The results obtained in this research show a ownership structure in innovative sectors that agrees with the ownership structure that Spanish companies have in general, with a high capital concentration (Ortega-Argiles et alii, 2005), especially held by banks and other financial entities (Tribo et alii, 2007), and a significant participation also of the board of directors (Acero-Fraile and AlcaldeFradejas, 2014). Although it is beyond the objective of this study to compare the ownership structure of innovative and non-innovative companies, if we compare our results regarding the ownership structure in innovative sectors and what has been previously stated by research on the ownership structure of Spanish firms in general, we cannot observe a lot of differences. It could mean that Spanish innovative companies do not have a specific ownership structure that really explains the orientation of these companies towards innovation.

In addition, if we compare our results with those obtained by previous research, and despite the inconclusive conclusions of this research, it does not seem that ownership structure of Spanish innovative sectors points towards significant shareholders that previous research shown as the most proactive towards innovation. Firstly, most of the studies advocate for a positive influence of foreign 
ownership on innovation (Choi et alii, 2011; Love et alii, 2009; Resende et alii, 2014) and, more specifically, on R\&D expenses (Ferris and Park, 2005; Hwang et alii, 2013; Lee, 2012; HyeogUg and Tomohiko, 2013). These authors argue that foreign ownership offers better options to access to resources for innovation and R\&D development (Brugger and Stuckey, 1987; Choi et alii, 2011), allow technological resources to be transferred, a major technical collaboration, and higher exchange of managerial resources and funding (Love et alii, 2009). 2015). From our results, domestic ownership seems to be much more important than foreign ownership. Secondly, most of the studies also highlight the conservative nature of financial entities and banks, which from our results are one of the most common types of institutional blockholders in Spanish innovative sectors. This negative relationship is mainly explained by the business links that banks maintain with firms, in the form of loans and credits, which expose banks, to the uncertainty of R\&D and innovation (Tribo et alii, 2007). Again, our results point to a relevant blockholder that does not seem to be very proactive to innovation. Finally, within the board, the most independent directors, who previous research undelines as proactive towards innovation, due to their major involvement in discussion and their richer experience and knowledge about other companies, are not the most numerous in Spanish innovative sector, neither the ownership held by them. All in all, our results confirm that ownership structure in Spanish companies does not seem to foster an appropriate innovative environment for innovation.

This research that analyses the ownership structure of Spanish companies belonging to innovative sectors does not pretend to explain or predict innovation. Our purpose is more limited, as we try to contribute to the existing literature by showing who are the major shareholders in Spanish innovative companies, and what are, if any, the most significant differences in the main blockhoders when different economic innovative sectors are compared and also differences over time. From our results, we extract some significant practical contributions, like the need to diversify the ownership structure of our companies in order to gain a major orientation towards innovation, letting other blockhoders to enter in the capital composition of Spanish companies more significantly, especially foreign capital of companies with high innovation indicators, and institutional and independent ownership. Finally, the findings obtained could serve to propose more ambitious future research that establishes what possible effects ownership structure could have on innovation. 


\section{References}

Acero-Fraile, I. and Alcalde-Fradejas, N. (2014). "Ownership structure and board composition in a high ownership concentration context". European Management Journal, 32 (4): 646-657.

Aldama Report (2003). Informe de la comisión especial para el fomento de la transparencia y seguridad en los mercados de las sociedades cotizadas. Available at: CNMV, <www.cnmv.es>.

Barros, H.M. (2015). "Exploring the use of patents in a weak institutional environment: The effects of innovation partnerships, firm ownership, and new management practices". Technovation, 45-46: 63-77.

Bellak, C. (2004). "How domestic and foreign firms differ and why does it matter?”. Journal of Economic Surveys, 18 (4): 483-514.

Belloc, F. (2012). "Corporate governance and innovation: A survey". Journal of Economic Surveys, 26 (5): 835-864.

Block, J.H. (2012). "R\&D investments in family and founder firms: An agency perspective". Journal of Business Venturing, 27 (2): 248-265.

Britton, J.N.H. (2003)."Network structure of an industrial cluster: Electronics in Toronto". Environment and Planning A, 35 (6): 983-1006.

Brossard, O., Lavigne, S. and Sakinc, M.E. (2013). "Ownership structures and R\&D in Europe: The good institutional investors, the bad and ugly impatient shareholders". Industrial and Corporate Change, 22 (4): 1031-1068.

Brugger, E.A. and Stuckey, B. (1987). "Regional economic structure and innovative behaviour in Switzerland". Regional Studies, 21 (3): 241-254.

Brunninge, O., Nordquist, M. and Wiklund, J. (2007). "Corporate governance and strategic change in SMEs: The effects of ownership, board composition and top management teams". Small Business Economics, 29 (3): 295-308.

Cassiman, B. and Veugelers, R. (2006). "In search of complementarity in innovation strategy: Internal R\&D and external knowledge acquisition". Management Science, 52 (1):68-82.

Chang, S.J. (2003). "Ownership structure, expropriation and performance of group-affiliated companies in Korea". Academy of Management Journal, 46 (2): 238-253.

Chang, S.J. and Hong, J. (2000). "Economic performance of group-affiliated companies in Korea: Intragroup resource sharing and internal business transactions". Academy of Management Journal, 43 (3): 429-448. 
Chang, S.J., Chung, C. and Marmood, I.P. (2006). "When and how does business group affiliation promote firm innovation? A tale of two emerging economies". Organization Science, 17 (5): 637-656.

Chen, H.L. and Hsu, W.T. (2009). "Family ownership, board independence, and R\&D investment". Family Business Review, 22 (4):347-362.

Chor, S.B., Il PARk, B. and Hong, P. (2012). "Does ownership structure matter for firm technological innovation performance? The case of Korean firms". Corporate Governance: An International Review, 20 (3): 267-288.

Choi, S.B., Lee, S.H. and Williams, C. (2011). "Ownership and firm innovation in a transition economy: Evidence from China". Research Policy, 40 (3): 441-452.

Crescenzi, R., Gagliardi, L* and Lammarino, S. (2015). "Foreign multinationals and domestic innovation: Intra-industry effects and firm heterogeneity". Research Policy, 44 (3): 596-609.

Dachs, B., Ebersberger, B. and Loof, H. (2008). "The innovative performance of foreign-owned enterprises in small open economies". Journal of Technology Transfer, 33 (4): 393-406.

David, P., Hitt, M.A. and Gimeno, J. (2001). "The role of institutional investors in influencing R\&D”. Academy of Management Journal, 44 (1): 144-157.

Davis, J.H., Schoorman, F.D. and Donaldson, L. (1997). "Toward a stewardship theory of management". Academy of Management Review, 22 (1): $20-47$.

Eisenhardt, K.M. (1989). “Agency theory: An assessment and review”, Academy of Management Journal, 14 (1): 57-74.

Ferris, S.P. and PArk, K. (2005). "Foreign ownership and firm value: Evidence from Japan". Advances in Financial Economics, 11: 1-29.

Fox, M.A. and Hamilton, R.T. (1994)."Ownership and diversification: Agency theory or stewardship theory". Journal of Management Studies, 31 (1)ः 69-81.

Gonzales-Bustos, J.P and Hernández-Lara, A.B. (2014). "An exploratory analysis of the board composition in Spanish innovative firms". European Accounting and Management Review, 1 (1):62-92.

Gonzales-Bustos, J.P. and Hernández-Lara, A.B. (2016). "Corporate governance and innovation: A systematic literature review". Corporate Ownership and Control, 13. Forthcoming.

Graves, S.B. (1988). "Institutional ownership and corporate R\&D in the computer industry". The Academy of Management Journal, 31 (2)ः417-428.

Grossman, S. and Hart, O. (1980). "Takeover bids, the free-rider problem, and the theory of the corporation". Bell Journal of Economy, 11 (1):42-64. 
Harris, R. and Moffat, J. (2013). "The direct contribution of FDI to productivity growth in Britain, 1997-2008". The World Economy, 36 (6):713736.

Hernández-Lara, A.B., Camelo-Ordaz, C. and Valle-Cabrera, R. (2014). "Does board member stock ownership influence the effect of board composition on innovation?". European Journal of International Management, $8(4): 355-372$.

Hernández-Lara, A.B., Camelo-Ordaz, C. and Valle-Cabrera, R. (2010). "The effects of boards of director son R\&D investments: The case of Spain". International Journal of Human Resources Development and Management, 10 (2): 152-165.

Hill, C.W. and SNELl, S. (1988). "External control, corporate strategy, and firm performance in research-intensive industries". Strategic Management Journal, $9(6): 577-590$.

Hoskisson, R.E., Hitt, M.A. and Hill, C.W.L. (1993)."Managerial incentives and investment in R\&D in large multiproduct firms". Organization Science, 4 (2): 325-341.

Hoskisson, R.E., Hitt, M.A., Johnson, R.A. and Grossman, W. (2002). "Conflicting voices: The effects of institutional ownership heterogeneity and internal governance on corporate innovation strategies". Academy of Management Journal, 45 (4): 697-716.

Hwang, J.H., Kim, M.S. and Chun, S.H. (2013). "The role of R\&D and corporate governance in Korea: IT firms versus non-IT firms". Information Technology and Management, 14 (1): 29-41.

HyeogUg, K. and Tomoнiкo, I. (2013). "What determines R\&D intensity? Evidence from Japanese manufacturing firms". Journal of Market Economy, 42 (1): 43-69.

Ito, B., Yashiro, N., Xu, Z., Chen, X.H. and Wakasugi, R. (2012). "How do Chinese industries benefit from FDI spillovers?". China Economic Review, 23 $(2) \div 342-356$.

Jensen, M.C. and Meckling, W.H. (1976). "Theory of the firm: Managerial behavior, agency costs and ownership structure". Journal of Financial Economics, $3(4) \div 305-360$.

KIM, C., YANG, K.H. and KIM, J. (2008). "A strategy for third-party logistics systems: A case analysis using the blue ocean strategy". Omega, 36 (4): 522 534.

Kim, N. and Kıм, E. (2015). "Board capital and exploration: from a resource provisional perspective". Management Decision, 53 (9): 2156-2174. 
Kochrar, R. and David, P. (1996). "Institutional investors and firm innovation: A test of competing hypothesis". Strategic Management Journal, 17 (1):73-84. Kor, Y.Y. (2006). "Direct and interaction effects of top management team and board compositions on R\&D investment strategy”. Strategic Management Journal, 27 (11): 1081-1099.

Latham, S.F. and Braun, M. (2009). "Managerial risk, innovation, and organizational decline". Journal of Management, 35 (2):258-281.

LEE, P.G. (2005). "A comparison of ownership structures and innovations of US and Japanese firms". Managerial and Decision Economics, 26 (1): 39-50.

Lee, P.G. and O'Neil, H.M. (2003). "Ownership structures and R\&D investments of US and Japanese firms: Agency and stewardship perspectives". Academy of Management Journal, 46 (2): 212-225.

LEE, S. (2012). "Financial determinants of corporate R\&D investment in Korea". Asian Economic Journal, 26 (2): 119-135.

Liu, S. (2012). "The study on the impact of ownership structure on the R\&D investment". International Conference on Management Innovation and Public Policy, 1-6: 1829-1834.

Love, J.H., Roperb, S. and Dua, J. (2009). "Innovation, ownership and profitability". International Journal of Industrial Organization, 27 (3)ः 424-434.

McConnell, J.J. and Servaes, H. (1990). "Additional evidence on equity ownership and corporate value". Journal of Financial Economics, 27 (2):595612.

Miozzo, M. and Dewick, P. (2002). "Building competitive advantage: Innovation and corporate governance in European construction". Research Policy, 31 (6): 989-1008.

Ortega-Argiles, R., Moreno, R. and Caralt, J. (2005). "Ownership structure and innovation: Is there a real link?". The Annals of Regional Science, $39(4) \div 637-662$.

R Core Team* (2013). "R: A language and environment for statistical computing. R Foundation for Statistical Computing, Vienna, Austria". <http://www.Rproject.org/>.

Resende, M., Strube, E. and Zeidan, R. (2014). "Complementarity of innovation policies in Brazilian industry: An econometric study". International Journal of Production Economics, 158 (1): 9-17.

Serapio, M.G.Jr. and Dalton, D.H. (1999)."Globalization of industrial R\&D: An examination of foreign direct investment in R\&D in United States". Research Policy, 28 (2-3): 303-316. 
Sundaramurthy, C. and Lewis, M. (2003). "Control and collaboration: Paradoxes of governance". Academy of Management Review, 28 (3): 397-415. Tribo, J.A., Berrone, P. and Surroca, J. (2007). "Do the type and number of blockholders influence R\&D investments? New evidence from Spain". Corporate Governance: An International Review, 15 (5): 828-842.

Tsao, S.M and Chen, G.Z. (2012). "The impact of internationalization on performance and innovation: The moderating effects of ownership concentration". Asia Pacific Journal of Management, 29 (3): 617-642.

VAN Der Elsta, C. (2004). "Industry-specificities and size of corporations: Determinants of ownership structures". International Review of Law and Economics, 24 (4): 425-446.

Wadhwa, A. and Котна, S. (2006). "Knowledge creation through external venturing: Evidence from the telecommunications equipment manufacturing industry". Academy of Management Journal, 49 (4): 819-835.

Wahal, S. and Mcconnell, J.J. (2000). "Do institutional investors exacerbate managerial myopia?”. Journal of Corporate Finance, 6 (3): 307-329.

Westphal, J.C. and ZAJAC, E.J. (1995). "Who shall govern? CEO/board power, demographic similarity, and new director selection". Administrative Science Quarterly, 40 (1):60-83.

XiAO, S. and Z ZAO, S. (2012). "Financial development, government ownership of banks and firm innovation". Journal of International Money and Finance, 31 (4): 880-906.

ZaHra, S.A. (1996). "Governance, ownership, and corporate entrepreneurship: The moderating impact of industry technological opportunities". Academy Of Management Journal, 39 (6): 1713-1735.

Zajac, E.J. and WestphaL, J.D. (1994)."The costs and benefits of managerial incentives and monitoring in large U.S. corporations: when is more not better?". Strategic Management Journal, 15 (S1): 121-142.

ZENG, T. and LIN, H.C. (2011). "Ownership structure and R\&D spending: Evidence from China's listed firms”. Chinese Management Studies, 5 (1)ः 82-93. Zhou, K.Z. (2006). "Innovation, imitation, and new product performance: The case of China". Industrial Marketing Management, 35 (3):394-402. 